\title{
The Effect of Appetitive Daytime Napping on Cognitive Functions
}

\section{Ikram Gündüz Uykusunun Bilișsel Fonksiyonlar Üzerindeki Etkisi}

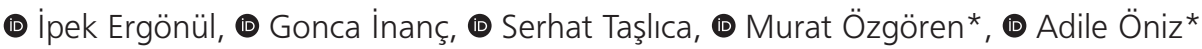 \\ Dokuz Eylül University Faculty of Medicine, Department of Biophysics, Izmir, Turkey \\ *Dokuz Eylül University Faculty of Medicine, Department of Biophysics, Sleep and Conscious States Technology Research and Application Center, Izmir, \\ Turkey
}

\begin{abstract}
Objective: The need for sleep is universal and its function is not completely clarified. Daytime alertness decreases after midday and one of the ways of preventing this decrease is daytime napping. The aim of this study is to investigate the effects 60-minutes appetitive daytime napping on cognitive performance.

Materials and Methods: This study was carried out at Dokuz Eylül University Faculty of Medicine, Department of Biophysics Sleep Dynamics Research Laboratory. Participants who came to the sleep laboratory in two different days slept one day and the other day were included in the control group. A total of 14 healthy individuals between age of 19-24 (5 male; mean age: $21.86 \pm 1.23$ years) without any neurological, psychological, chronic diseases, or sleep disorders were included in the study. Participants slept on their regular sleep pattern before both conditions. Various cognitive tests were administered to participants before sleep recordings. Electroencephalography was used on the purpose of following the sleep/wakefulness situation while sleeping. At the end of 60-minutes, the participants were woken up and after then same tests were performed again. On the control day, without sleep recording, determined questionnaires were applied to the participants. The resting period was set 60 -minutes as it was during the sleeping period.

Results: Cognitive performances of 14 participants on napping and control conditions were measured. The average duration of sleep was 57.3 ( \pm 3.57 ) minutes. Participants' scores of N-Back, Psychomotor Vijilans test, and Timewall tests on both conditions were examined. Although there were differences in the scores they were not significant. Conclusion: Daytime napping has different effects on cognitive functions. In future studies, it is aimed that the evaluation of the replacement and appetitive daytime napping in terms of the behavioral and sleep stages as electrophysiologically.

Keywords: Appetitive daytime napping, cognitive functions, reaction time, performance
\end{abstract}

Öz

Amaç: Uyku ihtiyacı evrenseldir ve işlevi tam olarak açıklığa kavuşturulmamıştır. Gündüz uyarılmışılık hali öğleden sonra düşüşe geçer. Bu düşüşü önlemenin yöntemlerinden biri de gündüz uykusudur. Bu araştırmanın amacı, ikram uykusu olarak uygulanan 60 dakikalık gündüz uykusunun bilişsel performans üzerindeki etkilerinin incelenmesidir. Gereç ve Yöntem: Çalışma, Dokuz Eylül Üniversitesi Tıp Fakültesi, Biyofizik Anabilim Dalı Uyku Dinamiği Araştırma Laboratuvarı'nda gerçekleştirilmiştir. Farklı iki gün laboratuvara gelen katılımcılar bir gün uyumuş diğer gün ise kontrol grubuna dahil edilmiştir. Çalışmaya 1924 yaş arasında nörolojik, psikolojik, kronik hastalığı olmayan ve uyku bozukluğu tanısı almamış toplam 14 sağlıklı birey (5 erkek; ortalama yaş: $21,86 \pm 1,23$ yıl) katılmıştır. Katılımcılar her iki koşul öncesinde normal uyku düzenlerinde uyumuşlardır. Uyku kaydının öncesinde katılımcılara çeşitli bilişsel testler uygulanmıştır. Uyku sırasında ise uyku/uyanıklık durumunu takip etmek amacıyla elektroensefalografiden yararlanılmıştır. Altmış dakikanın sonunda katılımcılar uyandırıımış ve sonrasında tekrar aynı testleri yapılmıştır. Uyku kaydının yapılmadığı kontrol gününde ise katılımcılara belirlenen anketler uygulanmıştır. Dinlenme süresi uyku süresinde olduğu gibi 60 dakika olarak belirlenmiştir.

Bulgular: Araştırmada 14 sağlıklı bireyin gündüz uykusu ve kontrol günlerindeki bilişsel performansları ölçülmüştür. Katılımcılar ortalama $57,3( \pm 3,57)$ dakika uyumuşlardır. Katılımcıların gündüz uykusu ve kontrol günlerindeki N-Back, Psikomotor Vijilans testi ve Timewall testleri skorları incelendiğine uyku sonrası farklılaşma görülse de anlamlı fark bulunamamıştır.

Sonuç: Gündüz uykusunun bilişsel fonksiyonlar üzerinde farklı etkileri bulunmaktadır. Ilerleyen araştırmalarda yedekleme ve ikram gündüz uykusunun davranışsal ve uyku evreleri açısından elektrofizyolojik olarak değerlendirilmesi hedeflenmektedir.

Anahtar Kelimeler: İkram gündüz uykusu, bilişsel fonksiyonlar, tepki süresi, performans

\section{Introduction}

The need for sleep is universal and since its function is not fully clarified the research on sleep is so extensive (1). However, sleep is not limited to night sleep alone. Daytime sleep, which is normal for babies and children in the life cycle, is also found in the daily routine for adults (2). 
Performance and arousal decrements and also drowsiness occur between 14:00 and 16:00, especially after lunch (3). Daytime napping is one of the methods that prevents this decrement (4). Daytime napping is defined as a sleep which is much shorter than the normal sleeping period commonly lasting from 30 to 90 minutes (5).

In the related literature, three types of daytime napping are defined. The first type is replacement naps and is taken in response to sleep deprivation and if people feel tired (6). This type of sleep generally reduces the effects of sleep deprivation in shift workers, it also enhances the cognitive functions and psychomotor performance and it also improves the cognitive functions -e.g. short-term memory-, psychomotor performance, and mood (5). The second type is prophylactic naps and taken mostly by shift workers prior to sleep loss as a "back-up" sleep (7). The third type is appetitive naps which are taken without sleep deprivation or fatigue (6). These sleeps form a two-phase sleep cycle with night sleep.

In daytime napping studies conducted without night sleep deprivation, Takahashi et al. (8) found a significantly lower P300 latency in the text translation task in 15 minutes napping condition compared to 45 minutes napping and no nap condition. They also reported the positive effect of appetitive naps on attention and performance (8). In another study of Takahashi et al. (8), they reported positive effects on perceived alertness following a 15 minutes napping. However, in terms of response time, they found no significant difference between daytime napping and no-nap condition (9).

The main aim of this study is to investigate the effects of 60 minute appetitive daytime napping on cognitive performance.

\section{Materials and Methods}

The research was performed in Dokuz Eylül University Faculty of Medicine, Sleep Dynamics Research Laboratory. The study has been approved by the Clinical Ethical Committee of Dokuz Eylül University no: 2017/18-44. Participants were informed about the study and their written informed consents were collected prior to protocols. In order to determine participants' sleep habits and current sleepiness status Pittsburgh Sleep Quality index (10) and the Epworth Sleepiness scale (11) were used respectively. The Symptom Checklist-90- Revised (SCL90R) (12) forms were used to determine previous diagnosis of any neurological or psychiatric disorders and The StateTrait Anxiety Inventory State form (STAI-TX1) (13) in order to determine anxiety levels. Participants with neurological, psychiatric, chronic diseases, sleep disorders and/or on any medication were excluded from the study. Participants came to the laboratory on two different days.

In order to get rid of order effect, half of the participants attended the sleep group first at the first day and control group on the second day. Other half of the participants had reverse order.

Fourteen healthy individuals between age of 19-24 (5 male; mean: $21.86 \pm 1.23$ years) were recruited for the study. Participants were asked to avoid foods and drinks that would affect sleep/wakefulness statuses the night before the tests and the day the tests were administered. In the cases where alcohol, drug or another substance use were detected within the time period that would affect the recordings, participants' recordings were postponed to another day. Also, participants were asked to sleep in their normal sleep patterns the night before the recordings.

Participants slept in an electromagnetically isolated room for 60 minutes. Their sleep condition was defined as appetitive daytime napping since their previous night sleep was not restricted. The recording room walls were also insulated with acoustic material to prevent noise from outside. Communication with the participants was provided by the audio system between the recording and observation rooms. All subjects were recorded by video during their sleep with their consents.

Participants' sleep duration was determined to be 60 minutes and sleeping hours were determined as 14.30-15.30. At the end of this period participants were awakened.

Psychomotor Vigilance Test (PVT), N-Back, and Timewall tests were administered prior to sleep which were selected based on the cognitive functions they are intended to evaluate. Electroencephalography (EEG) was used during sleep to monitor sleep/wakefulness status. Evaluation of EEG data for sleep stages was made according to the American Academy of Sleep Medicine scoring system. The same tests were repeated 15 minutes after the participants awakened.

On the control days, where participants were on no-nap condition, the same forms and tests were administered. The period between tests were determined as 75 minutes as in daytime napping condition.

PVT measures psychomotor vigilance, alertness, sustained attention and simple reaction time (14). Timewall test is a visual spatial perception test and measures the time perception (15). The N-Back test evaluates vigilance, sustained attention, visual memory, executive functions and short-term working memory. The Psychology Experiment Building Language battery was used for the administration of cognitive tests and they were selected based on the cognitive functions they intended to evaluate.

\section{Statistical Analysis}

SPSS 22.0 was employed for the statistical analysis. ShapiroWilk test was used for controlling the normal distribution of the data groups. Wilcoxon signed-rank test was performed to compare pre-post differences of test performances in different days.

\section{Results}

In this present study, the cognitive performances of 14 healthy participants on appetitive daytime napping and control conditions were measured.

Mean value of night sleep time for all participants was 7.1 $( \pm 0.96)$ hours. Participants had an average sleep time of 57.3 $( \pm 3.57)$ minutes during daytime napping condition. All of the participants had Stage- 1 and Stage- 2 during their sleep. 12 participants had Stage- 3 and only two of them had rapid eye movement (REM) sleep. Average stage durations of the participants are given in Table 1. 


\begin{tabular}{|c|c|c|}
\hline \multirow[b]{2}{*}{ Sleep stages } & \multicolumn{2}{|c|}{ Duration (minute) } \\
\hline & Mean & SD \\
\hline Wake & 12.11 & 11.79 \\
\hline Stage-1 & 9.61 & 7.11 \\
\hline Stage-2 & 14.25 & 6.06 \\
\hline Stage-3 & 19.93 & 12.08 \\
\hline REM & 1.14 & 4.00 \\
\hline
\end{tabular}

\section{N Back Response Times}

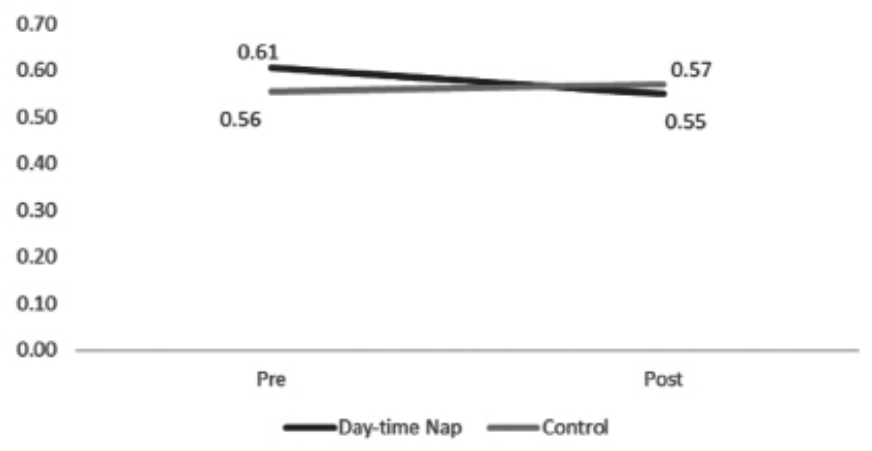

Figure 1. Comparison of condition effect (daytime napping and control) and test administration time (pre, post) of N-Back test response time

Six participants awakened themselves and eight were awakened by the operator at the end of 60 minutes. One, four, and three participants were in Stage-1, Stage-2, and Stage-3, respectively when they were awakened.

Participants' response times in the N-Back test are given in Figure 1. A Wilcoxon signed-rank test was conducted to examine the effect of condition (daytime napping, control) on N-Back test response times. No statistically significant effect of condition on test scores was found. Although the participants reacted faster following daytime napping condition, the difference was not statistically significant ( $z=-1.648, p=0.099)$.

Participants' correct answer scores in the N-Back test are given in Figure 2. A Wilcoxon signed-rank test was conducted to examine the effect of condition (daytime napping, control) on $\mathrm{N}$-Back test correct answers. No statistically effect of condition on test scores was found. Although the participants had lower correct answer scores following daytime napping condition, the difference was not statistically significant $(z=-1.026, p=0.305)$. Participants' response times in the PVT test are given in Figure 3. A Wilcoxon signed-rank test was conducted to examine the effect of condition (daytime napping, control) on PVT test. No statistically significant effect of condition on test scores was found. Although the participants reacted slower following daytime napping condition, the difference was not statistically significant $(z=-0.973, p=0.331)$.

Participants' accuracy rates in the Timewall test are given in Figure 4. A Wilcoxon signed-rank test was conducted to

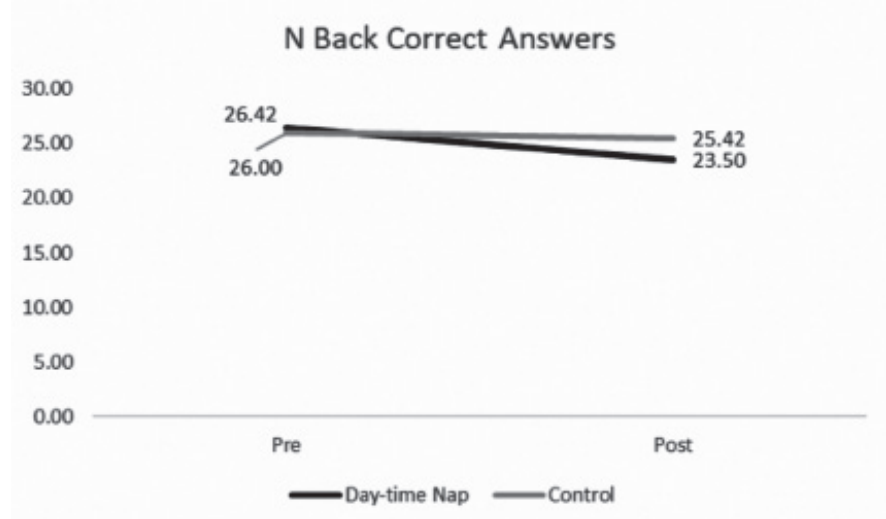

Figure 2. Comparison of condition effect (daytime napping and control) and test administration time (pre, post) of N-Back test correct answers

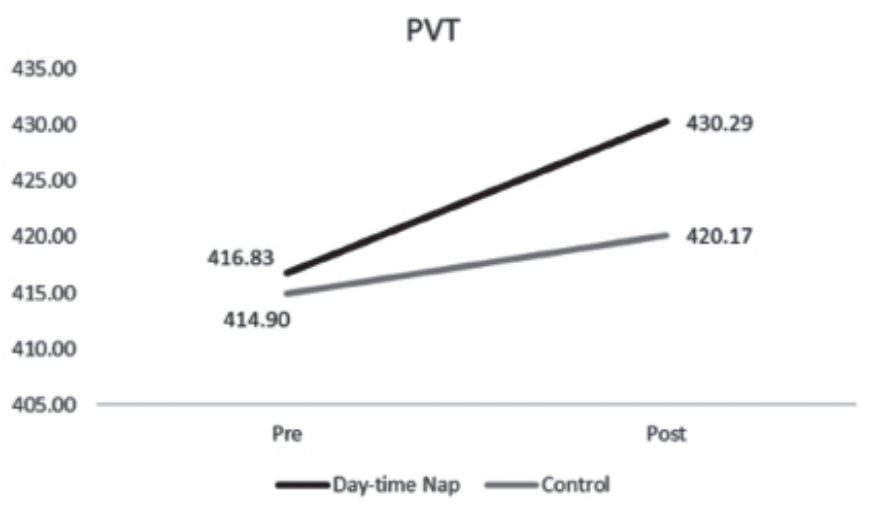

Figure 3. Comparison of condition effect (daytime napping and control) and test administration time (pre, post) of Psychomotor Vijilans test response time

PVT: Psychomotor Vijilans test

Timewall Accuracy Rates

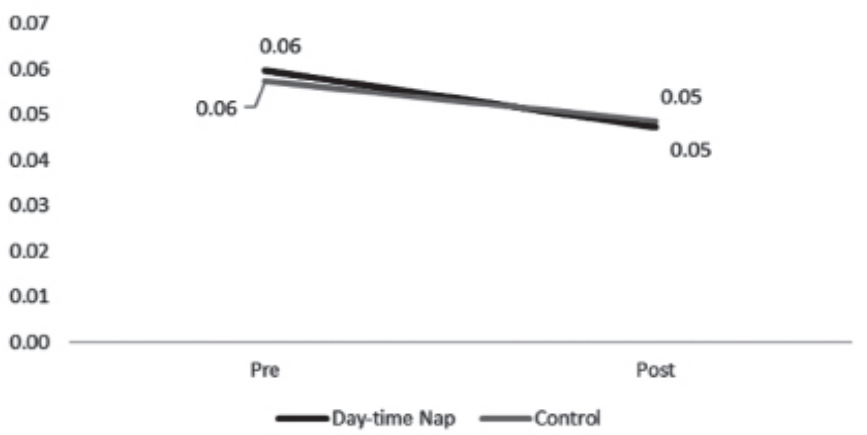

Figure 4. Comparison of condition effect (daytime napping and control) and test administration time (pre, post) of Timewall test accuracy rates

examine the effect of condition (daytime napping, control) on accuracy rates in the Timewall test. No statistically significant effect of condition on test scores was found. The accuracy 
rates are higher in the post-test condition, but the difference between condition and time was not statistically significant ( $\mathrm{z}=-$ 0.408, $\mathrm{p}=0.683$ ).

\section{Discussion}

This study has provided data on the effects of appetitive daytime napping on cognitive performance.

In the related literature both positive and negative effects of daytime napping have been reported. This effect varies depending on whether the daytime napping is habitual, the length of daytime napping, the time of day nap is taken, the amount of daytime sleepiness, and the stage and/or the condition the individual is awakened from daytime napping (6). In a study Hayashi et al. (4) conducted, they investigated the effect of $20 \mathrm{~min}$. daytime napping in non-habitual nappers for five consecutive days. They found that although not significant, the performance enhancements of a $20 \mathrm{~min}$. nap occur after the third day (4).

Hayashi et al. (3) reported positive effects of only a 20 min nap on the emotional state, performance, and EEG activity.

In a study restricting the nocturnal sleep, participants were awakened from different sleep stages (Stage-1, Stage-2). The effects of sleep stages on performance and vigilance were examined. The performance of participants who had naps including Stage-2 improved (16). Evans et al. (1) and Dinges et al. (17) reported that appetitive nappers have more Stage- 1 sleep, also have more transition between sleep stages. In addition, for both replacement and appetitive naps, no REM stage was found. However, Mednick et al. (18) reported a positive effect of appetitive naps which includes slow wave sleep and REM sleep on learning. On the other hand, Hayashi et al. (3) reported that the increase in performance after daytime napping was not always due to slow wave sleep. In our study, although the data of sleep stages were present for participants, due to low number of participants in each group no statistical comparison was performed.

\section{Conclusion}

In the related literature, it has been reported that people suffer from inertia after having daytime napping. However, this period of inertia does not exceed 15 minutes (6). In the light of this knowledge, in our study tests were administered 15 minutes after awakening. Consistent with the aforementioned study, there were no significant vigilance differences between the sleep and control group. But a decrease in vigilance (decrease in reaction time in PVT) was observed. This decrease might be the result of individual differences in sleep inertia recovery period, i.e. some of participants had not recovered from sleep inertia during the tests.

In the future studies it is aimed to investigate differences between replacement naps with restricted night sleep and appetitive naps in terms of the behavioral changes and electrophysiologically evaluated sleep stages in participants who have completed the sleep cycle rather than daytime naps with predetermined period.

\section{Ethics}

Ethics Committee Approval: This study has been approved by the Ethics Committee of Non-Interventional Research in Dokuz Eylül University (date: 31.07.2017; no: 2017/18-44).

Informed Consent: Participants were informed about the study and their written informed consents were collected prior to protocols.
Peer-review: Externally and internally peer-reviewed.

\section{Authorship Contributions}

Concept: İ.E., A.Ö., Design: I.E., M.Ö., Data Collection or Processing: I.E., G.I., S.T., Analysis or Interpretation: I.E., S.T., M.Ö., A.Ö., Literature Search: I.E., G.I., S.T., Writing: A.Ö., M.Ö., I.E., G.I., S.T.

Conflict of Interest: No conflict of interest was declared by the authors.

Financial Disclosure: The authors declared that this study received no financial support.

\section{References}

1. Evans FJ, Cook MR, Cohen HD, Orne EC, Orne MT. Appetitive and replacement naps: EEG and behavior. Science 1977;197:687-9.

2. Milner CE, Cote KA. Benefits of napping in healthy adults: impact of nap length, time of day, age, and experience with napping. J Sleep Res 2009;18:272-81.

3. Hayashi $M$, Watanabe $M$, Hori T. The effects of a 20 min nap in the midafternoon on mood, performance and EEG activity. Clin Neurophysiol 1999;110:272-9.

4. Hayashi M, Fukushima $H$, Hori T. The Effects of short Daytime Naps for Five Consecutive Days. Sleep Res Online 2003;5:13-7.

5. Lovato $N$, Lack $L$. The effects of napping on cognitive functioning. Prog Brain Res 2010;185:155-66.

6. Dinges DF. Adult Napping and Its Effects on Ability to Function. In: Stampi C, editor. Why We Nap [Internet]. Boston, MA: Birkhäuser Boston; 1992 [cited 2017 Oct 4]. p. 118-34. Available from: http://link.springer. com/10.1007/978-1-4757-2210-9_9.

7. Stampi C. Why we nap: evolution, chronobiology, and functions of polyphasic and ultrashort sleep [Internet]. Boston: Birkhäuser; 1992 [cited 2017 Sep 11]. Available from: http://books.google.com/ books?id=LYIFAQAAIAA]

8. Takahashi M, Fukuda $\mathrm{H}$, Arito $\mathrm{H}$. Brief naps during post-lunch rest: effects on alertness, performance, and autonomic balance. Eur I Appl Physiol Occup Physiol 1998;78:93-8.

9. Takahashi M, Nakata A, Haratani T, Ogawa Y, Arito H. Post-lunch nap as a worksite intervention to promote alertness on the job. Ergonomics 2004;47:1003-13.

10. Ağargün MY, Kaya H, Anlar Ö. Pittsburgh Uyku Kalitesi Indeksinin Geçerliğ ve Güvenirliği. Türk Psikiyatri Derg 1996;7.

11. Ağargün MY, Çilli AS, Kara H, Bilici M, Telcioğlu M, Semiz ÜB, Başoğlu C. Epworth Uykululuk Ölçeğinin geçerliği ve güvenirliği. Türk Psikiyatri Derg 1999;10:261-7.

12. Kılıç M. Belirti Tarama Listesi (SCL-90-R)'nin Geçerlilik ve Güvenirliği. Türk Psikolojik Danışma Ve Rehb Derg 1991;1:45-52.

13. Öner N, Le Compte A. Durumluk-Sürekli Kaygı Envanteri El Kitabı. İstanbul: Boğaziçi Üniversitesi Yayınları, 1985.

14. Wilkinson RT, Houghton D. Field test of arousal: a portable reaction timer with data storage. Hum Factors 1982;24:487-93.

15. Englund CE, Reeves DL, Shingledecker CA, Thorne DR, Wilson KP. Unified Tri-Service Cognitive Performance Assessment Battery (UTC-PAB). 1. Design and Specification of the Battery. U. S. Army Medical Research and Development Command; 1986.

16. Hayashi M, Motoyoshi N, Hori T. Recuperative power of a short daytime nap with or without stage 2 sleep. Sleep 2005;28:829-36.

17. Dinges DF, Orne MT, Orne EC, Evans FJ. Voluntary self-control of sleep to facilitate quasi-continuous performance. U.S. Army Medtcal Research and Development Command; 1980.

18. Mednick S, Nakayama K, Stickgold R. Sleep-dependent learning: a nap is as good as a night. Nat Neurosci 2003;6:697-8. 